\author{
Adam Drobniak \\ University of Economics in Katowice \\ e-mail: adam.drobniak@ue.katowice.pl \\ ORCID: 0000-0002-1421-2923
}

\title{
DEVELOPMENT IN REGIONS LAGGING BEHIND - THE CASE OF COAL AND POST-COAL REGIONS
}

\section{ROZWÓJ W REGIONACH ZAPÓŹNIONYCH - PRZYKŁAD REGIONÓW WĘGLOWYCH I POWĘGLOWYCH}

\author{
DOI: $10.15611 /$ br.2020.1.02 \\ JEL Classification: $\mathrm{O} 18$
}

\section{(C) 2020 Adam Drobniak}

This work is licensed under the Creative Commons Attribution-ShareAlike 4.0 International License. To view a copy of this license, visit http://creativecommons.org/licenses/by-sa/4.0/

Quote as: Drobniak, A. (2020). Development in regions lagging behind - the case of coal and post-coal regions. Biblioteka Regionalisty. Regional Journal, (20).

\begin{abstract}
The main topic of the paper refers to the issues of economic transition in regions. The research question is to determine the nature of current development processes in regions lagging behind, in coal regions in particular. The main goal of the article is to present selected modern concepts indicating the paths of the effective reorientation of development processes of such regions, along with their application into the policy framework for the coal regions' transition. Methodically, the paper is based on a desk research and statistical analysis of time series covering GDP dynamics and job growth for NUTS3 regions in the European Union (EU). The main findings of the research indicate the significant scale of the economic challenges of coal regions in terms of their low productivity measured by the trade-off between the growth of GDP and the increase in the number of jobs, as well as the need to define a complex policy framework which 'mixes' a sectoral and territorial approach to achieve an effective coal regions' transition.
\end{abstract}

Keywords: regions lagging behind, coal regions, productivity.

Streszczenie: Tematyka artykułu nawiązuje do zagadnień transformacji gospodarczej regionów. Problemem badawczym jest określenie charakteru obecnych procesów rozwoju w regionach zapóźnio- 
nych, w szczególności w regionach węglowych. Głównym celem artykułu jest prezentacja wybranych współczesnych koncepcji wskazujących skuteczne ścieżki reorientacji rozwoju regionów zapóźnionych wraz z ich wykorzystaniem do sformułowania ram polityki na rzecz transformacji regionów węglowych. Artykuł bazuje na przeglądzie literatury oraz analizie statystycznej szeregów czasowych obejmujących dynamikę PKB i przyrost miejsc pracy dla regionów NUTS3 w Unii Europejskiej. Główne rezultaty wynikające z badań wskazują na znaczną skalę wyzwań ekonomicznych regionów węglowych ujmowanych w kategoriach niskiej ich produktywności mierzonej relacją między wzrostem PKB a wzrostem liczby miejsc pracy, a także na potrzebę zdefiniowania kompleksowych ram polityki, które łączą podejście sektorowe i terytorialne na rzecz skutecznej transformacji regionów węglowych.

Słowa kluczowe: regiony zapóźnione, regiony górnicze, produktywność.

\section{Introduction}

Some regions, especially in the context of the European Union's (EU) cohesion policy, are perceived in terms of the so-called lagging behind regions (Bachtler, Martins, Wostner, and Zuber, 2019; Barzotto, Corradini, Fai, Labory, and Tomlinson, 2019). This means that in economic terms, regions of this type are characterized by low productivity and low (or negative) growth in reference to other regions of a given country, or in a broader perspective, in relation to other regions of the EU. The sources of low productivity are most often rooted in the outdated paths of the regions' development in terms of the global economy and contemporary development challenges. These paths are usually characterized by the dominance of low-tech sectors, a strong dependence on traditional declining industries, weak knowledge networks and a lack of international business connections.

Despite these difficulties, the desired dynamism of development together with the improvement in the productivity of regions lagging behind meet with several challenges. Firstly, new competitive advantages based on the specific potentials and opportunities of such a given region should be sought and created, rather than imitating actions from other regions. Secondly, potential competitive advantages should be translated into new development paths, including those based on a related and unrelated variety (Boschma and Immarino, 2009; Boschma, Minondo, and Navarro, 2012; Frenken, Van Oort, and Verburg, 2007; Solheim, Boschma, and Herstad, 2018). The related variety may result from the development of related sectors, e.g. the IT industry grew out of services provided for the traditional industries. The unrelated variety is often a consequence of successfully attracting to a slower developing region external investors allocating capital to new sectors of the economy, or developing local entrepreneurship. Thirdly, regaining development dynamics as well as the scale and socio-economic importance requires ensuring a certain concentration of the development's actors and an appropriate number of projects. This type of 'density' of actors and activities is the condition for triggering the effects associated with the agglomeration externalities, which consequently 
determine synergy effects. Fourthly, the vision of development of a region lagging behind should be properly defined, clearly emphasizing the bold thematic challenges that the region should meet, and whose implementation is possible due to the specific potentials and strengths.

Given the above, the research question raised in the paper is to determine the nature and scale of current development processes of lagging-behind regions, in particular coal and post-coal regions, in terms of economic growth and the increase in the number of jobs, which ultimately determine the level of low productivity of such areas. In this context, the main goal of the article is to present selected modern concepts indicating the paths of effective reorientation of development processes of regions lagging behind along with their application into policy framework for the coal regions' transition. This approach contributes to overcoming the cognitive gap for policymakers to define a policy framework for coal region's transition in a rational way, i.e. combining regional context threads with conceptual arguments.

The methodological procedure is reflected by the individual parts of the paper. The first part is based on desk research and presents several modern development concepts, from evolutionary economic geography, focused on dynamizing the development processes of lagging-behind regions. The second part, which is also based on desk research, presents the synthetic characteristics of the lagging-behind region category and one of its type, i.e. the coal region. The third part, of an empirical nature, is based on the economic analysis of GDP dynamics and the number of job changes in the EU regions on NUTS3 level ( $n=1,270$ regions). It contains a proposal of the research framework, which combines the value of GDP dynamics with the value of job dynamics, along with their trade-off used to classify regions into four groups. Consequently, the research framework is helpful to characterize the economic conditions of the EU coal regions, and to show their differences in reference to other EU regions. The paper ends with a discussion and conclusions. This part links the theoretical findings (from the presented modern re-development concepts) with the economic distinctness of the EU coal regions (shown in the empirical study), in order to propose a political framework for the effective transition of such areas.

\section{Selected concepts for re-development of regions lagging behind}

First, the re-development of lagging-behind regions should be embedded in the theoretical concepts of evolutionary economic geography. This kind of reference, i.e. an examination of the contemporary achievements of regional studies in the field of regional transition, consequently facilitates more rational assumptions for policy framework and programming the economic reorientation of such regions.

Bearing in mind the lagging-behind region, including those with a coal legacy, the following can be considered as legitimate in the process of creating new paths of development: (1) concepts related to increasing productivity of the region's economy 
along with spillover effects, (2) concepts connected with related and unrelated variety along with regional innovation systems, and (3) the concept of a polycentric urban region. These are just a few of the existing concepts for the transition of regions. Their selection was based mainly on the criterion of contemporary ideas that have the potential to change such a region's development path in an effective way.

It is obvious that a broader theoretical perspective could even refer to other concepts e.g.: path dependence and uneven development (Harvey, 2005; Martin and Sunlay, 2006), resilience (Briguglio, Cordina, Farrugia, and Vella, 2006; Simmie and Martin, 2009; Folke et al., 2010; Hassink 2010; Drobniak 2012; Martin and Gardiner, 2019), complexity theory and adaptive systems (Fontana 2013; Martin and Sunley, 2007), the diffusion of innovation and learning models (Duranton and Puga, 2004; Rogers 2003), and foreign direct investment (Aitken and Harrison 1999; Barry, Görg, and McDowell, 2003; Fu and Gong 2011; Girma and Wakelin, 2007). However, this broader theoretical perspective along with its impact on the transition of coal regions goes beyond the form of this paper and requires further studies.

\subsection{Increasing productivity of regional economy}

Studies conducted on the productivity of regions (in terms of labour productivity, i.e. an increase in GDP per worker) clearly show that a high level of productivity is achieved by regions where there is a higher level of entrepreneurship, higher technological capacity, and a well-functioning knowledge exchange network, i.e. leading regions (Bachtler et al., 2019). On the other hand, regions which are lagging behind are characterized by the dominance of low-tech industries, a high dependence on traditional or declining industries, and weak business connections. As a consequence these features significantly impede or even seriously limit the identification of new activities or gaining market opportunities, which should be supported by appropriate public intervention.

Recommendations for lagging-behind regions resulting from the concept of productivity growth point to taking actions that enable the transition of economic entities from suppliers towards value creators in global value chains, mainly by strengthening and extending the added value in commercial goods industries, i.e. those traded on international markets (Bachtler et al., 2019). This kind of reinforcement and expansion can occur by the learning and diffusion processes from the leading regions, and by identifying and minimizing diffusion barriers. In such regions, these significantly limit: the use of new technologies, strengthening the mobility of human and financial capital, stimulating trade flows, intensifying investment in knowledge, initiating actions related to spillover effects. Adaptation by minimizing the indicated barriers facilitates the diffusion of development effects from leading to laggingbehind regions.

It should also be emphasized that the scale of spillover effects is still largely determined by the geographical proximity between the leading and the regions 
lagging behind (Micek, 2017). The greater the geographical distance from the leading region, the greater the challenges of transition and the creation of an appropriate innovation ecosystem in the lagging region.

\subsection{Related and unrelated variety along with regional innovation systems}

The concept of related and unrelated variety indicates that the innovation capacity of a region's economy should not be seen solely from the perspective of expenditure on research and development $(\mathrm{R} \& \mathrm{D})$, but rather through that of experience accumulated in the entire organization of the economy and in a given place where this accumulation occurs (Solheim et al., 2018). Generally, in the concept of related and unrelated diversity and in the studies on innovation, it is argued that knowledge is a product of experience, and associated with individuals whose interactions in the organizational and territorial context shape the innovation of companies and paths of regional development (Lundvall and Johnson, 1994).

The concept of related and unrelated variety also underlines the fundamental importance of the diversity of human capital (diversity of origin, education, knowledge, experience), since this kind of diversity strengthens the creation of knowledge and the generation of innovation, and increases the absorption capacity of enterprises, i.e. the ability to identify, assimilate and use external knowledge (Cohen and Levinthal, 1990).

In terms of application, the concept of related and unrelated variety is recognized in three aspects: (1) the appropriate 'composition' of the region's economy, (2) the appropriate portfolio of industries and sectors, (3) the increasing diversity of the region's economy in the long term.

In the aspect of sectoral 'composition', it is argued that this 'composition', like inputs, determines the region's growth dynamics (Frenken et al., 2007). Sectoral 'composition' draws attention to whether spillover effects (related to a given innovation) occur only within companies in a given sector (related variety), or whether the spreading effects are recorded between companies in various sectors (unrelated variety). In this way, diversity, and in particular its precise 'composition' becomes a source of economic growth in the region. This means that only some sectors are complementary in their joint existence within a region's economy, causing an additional impulse for its growth.

Related and unrelated variety is also analyzed in the context of resilience, i.e. diversity is perceived as a portfolio strategy to protect the region against economic shocks (Boschma and Franken, 2007). In this case, we are talking about regional diversification, in which the high diversity of the regional economy (a large number and diversity of industries) is conducive to minimize the negative effects of the crisis in one sector. The portfolio strategy seems to be definitely more advantageous than creating a region's economic development based on one specialization.

The latest approach to the concept of related and unrelated variety combines the concepts of diversity and economic growth in the long run. According to this 
approach, the economy of the region, which in the long term does not increase sectoral diversity, will be exposed to stagnation and structural unemployment (Pasinetti, 1993). In this regard, the development of new sectors of the economy appears as a necessity for the absorption of human capital released from other sectors entering the maturity and decline phase, or being subject to technological changes reducing the amount of human labour (an improvement in efficiency by decreasing the labour intensity). This approach also has a territorial reference, i.e. new sectors usually arise in leading regions, including those with an urbanized and metropolitan character, while older, more traditional sectors dominate in lagging-behind regions. This lack of balance brings effects in the form of the flow of human and financial capital from regions lagging behind (Frenken et al., 2007).

Issues of related and unrelated diversity, as well as categories of dissemination effects are close to the contemporary development concepts related to regional innovation systems and smart regional specializations. Regional innovation systems are rooted in the experiences of innovation systems from the 1980s (Asheim, Isaksen, and Trippl, 2019). The theoretical assumptions of innovation systems are in opposition to neoclassical economics, and emphasize the role of innovation, its dynamics and imbalance in contemporary economic processes (Weber and Truffer, 2017). Consequently, innovation is recognized in terms of the result of the process, namely non-linear, collaborative, cumulative learning which shapes formal and informal institutions at various territorial levels.

In diagnosing and programming the development of regional innovation systems, their several types can be identified. The first referred to the 'territorially rooted innovation system' (Cooke, 1998), and is distinguished by the innovative activity of companies based mainly on the strictly territorially localized learning process between companies, stimulated by geographical proximity and interaction with institutions providing knowledge ( $\& \& D$, universities). This model of a regional innovation system (RIS) distinguishes a market approach in which the demand side determines the dynamics and directions of innovation. An example of this type of RIS is the Emilia-Romagna region (Italy).

The second type of RIS refers to the 'regionally networked innovation system', in which, as in the first case, there are companies and institutions rooted in the 'tissue' of a given region, but this system is definitely planned by initiating a public-private partnership. A significant role is played by regional R\&D units and other institutions working together toward innovation, labelled as the 'mix' model of supply and demand interactions, and represented by RIS operating in Germany, Austria and the Scandinavian countries (Asheim et al., 2019).

The 'regionalized national innovation system' is the third type of RIS. As part of it, there is a functional integration of parts of industry and institutions supporting national or international innovation systems, which means that innovation activities take place in cooperation with actors from outside the given region, and thus the system resembles a sectoral innovation system (Cooke, 1998; Cooke, Parrilli, and 
Curbelo, 2012). An example of this type of innovation system is the cluster initiatives of large companies whose R\&D departments cooperate with government institutions in technology parks or technopolies. These types of technopolies are planned as innovative milieu characterized by a high level of concentration of resources and knowledge, but with a weak connection with the local economic environment, a kind of enclave of innovation (Phelps and MacKinnon, 2000) found in France, Japan and Taiwan.

\subsection{Polycentric urban region}

The last of the presented modern concepts of regional development, particularly interesting for enhancing of the growth of the lagging-behind region, is the polycentric urban region. Its sources can be traced to the earlier approaches related to the analysis of interdependencies between cities (Houtum and Langendijk, 2001), including categories related to: urban field, city systems, and urban networks. The concept of urban networks, and also city networks, is based on the assumption of horizontal links between cities of different sizes and ranks. Linkages of this type are determined by such factors as the international mobility of human capital, the occurrence of spatial and a-spatial corridors (e.g. high-quality transport infrastructure and ICT infrastructure) being gateways of high economic activity areas, functioning of interdependence channels, an information flow (in horizontal connections there is a circulation of specialized information, i.e. information that is used to make decisions in a given territorial unit). The concept of a polycentric urban region is perceived as a way of strategic planning and as an alternative of development for cities of lower rank (lagging-behind regions) in contrast to large cities (first-tier cities) that are capital cities or also centres of metropolis on a global scale (leading regions). According to the European Commission (1999), a polycentric urban region is a spatially close, connected and strategically planned region with historically and politically different cities, without a clear hierarchy between them, with cities separated by open space. A polycentric urban region means a territorial strategic product that allows achieving a higher impact scale and higher competitiveness (than typical individual metropolitan cities) by interlinking independent (non-metropolitan) cities within a functional region. In this way, the socio-economic growth of the territory is determined not only by the scale and rank of urban centres, but also by the system of their interrelationships. The studies which show the polycentric urban regions in Europe, are (Taylor and Pain, 2007): Dutch Randstad (Amsterdam, Rotterdam, Hague, Utrecht), Belgian Diamond (Brussels, Ghent, Antwerp, Leuven), the German area of the Ruhr and Rhine (key cities: Dusseldorf, Cologne, Dortmund, Essen, Bochum), and Central Scotland (key cities: Glasgow, Edinburgh) (Bailey and Turok, 2001).

A polycentric urban region is a strategic concept, which means that shaping

the development of this type of region requires defining the role of regional 
identification. A polycentric urban region develops and positions itself through a process of regional identification under which 'labeling' (as in the case of Randstad or the Flemish Diamond) is the definition of shared ideas about the region and its development, and as a consequence of its development objectives. According to Houtum and Lagendijk (2001), the identification of a polycentric urban region is carried out in three dimensions, i.e. strategic, cultural and functional. The strategic dimension means the need to define common perspectives and development goals for the given area. The starting point may be the perception of a polycentric urban region as: (1) a response to increasing competitiveness between cities, (2) an efficiently functioning network of cities which regulates flows of human capital, information, knowledge, and goods in order to create faster growth and higher productivity, (3) a response to the challenge of gaining the appropriate rank and compete in the global network of cities (transition of lagging-behind regions).

The cultural dimension is associated with the change in the perception of cities in the polycentric urban region from 'others' into the term of 'we'. Cultural identification is a dynamic and long-term process in which a shared sense of belonging and the idea of living in a given community are created and strengthened.

Several elements make up the functional dimension of the polycentric urban region. The first involves setting the boundaries of this type of space, which is most often delimited by a collection of cities in which the travel time between them is in the range of 1 to 1.5 hours travel time (Kwon and Seo, 2018). The second element is the coherence of connections within a polycentric urban region, which may take the form of infrastructural, economic, political, educational, business services, etc. The coherence of connections is perceived as a factor strengthening the international competitiveness of the polycentric urban region. An example of this kind of consistency refers to solutions in the field of transport infrastructure (a coherent system of higher-order roads, and a coherent system of railway and energy infrastructure). An example of economic coherence can be the various sectoral and industrial specializations and their respective 'composition'.

\section{Coal and post-coal regions as lagging-behind regions}

The features of these regions (like low productivity, and low productivity growth) are additionally negatively strengthened by at least several factors. First, in these regions there is a high sensitivity of the regional economy, i.e. low economic resilience (Drobniak, Polko, and Suchacek, 2017) resulting from relatively standard products supplied by traditional industries, which are vulnerable to various types of economic shocks occurring in the global economy. These products are also subject to strong competitive pressure from countries and regions with lower production costs. Secondly, in these regions one encounters a poorly developed and sensitive innovation ecosystem (i.e. a small number of innovative companies, a weak base of 
business-related institutions supporting innovative companies, including, e.g. higher education, technology parks and incubators, capital funds focused on innovations implementation), and a small number of connections of the regional innovation ecosystem with actors from the global environment (Asheim et al., 2019). Thirdly, the two above factors are additionally accompanied by relatively weak institutional abilities manifesting themselves both in the categories of norms (e.g. cooperation, business standards) and institutions (staff competences and leadership skills in determining new development paths).

In lagging-behind regions this negative configuration of unfavourable factors results in series of negative effects, not only economic, but also socio-cultural as well as environmental-infrastructural. On the socio-cultural side, the negative effects include among others: the outflow of human capital at the age of highest professional mobility, a severely ageing society, a stereotypical and unfavorable image of the region (Krzysztofik, 2012).

One of the side effects in these regions, in environmental-infrastructural and territorial perspectives, is the excessive pollution of the environment (water, soil, air), a significant amount of undeveloped areas and post-industrial facilities, and a weak ability to adapt the existing infrastructure to the needs of modern economy (European Commission, 2017). These indicated negative effects accumulate on relatively small areas of cities, subregions, and generate challenges to search for new development paths which often exceed the capabilities of local government or the traditional business sector.

The quality of life in lagging-behind regions, including those in transition from industrial to post-industrial structures, is perceived as low in terms of work, place of residence and services (Drobniak, 2012). This kind of perception is further negatively intensified by comparing to other, often neighbouring regions, which have developed in a vibrant way in terms of: higher productivity, various development paths, presence of modern industries, diverse and specialized products, a wellfunctioning innovation ecosystem, high institutional capabilities, population growth, and positive image (i.e. leader regions).

As pointed out by Dijkstra, Poelman and Rodríguez-Pose (2018) and Rodríguez-Pose (2018), in regions lagging behind there is a high risk of the geography of the discontent phenomenon, which manifests itself by the feeling of people of being left with the problem. The attitudes of dissatisfaction additionally hinder the adaptation of such regions to the challenges of the global economy, political and economic reforms, and social change. The effect of discontent manifests itself usually by a strong resistance to change, along with populist attitudes and denying the need for change.

The strategic approach to the development of regions lagging behind is a complex task, because creating the new socio-economic activities, gaining market opportunities and setting up challenges for the policy programming for such territories are particularly difficult. As evidenced by the examples of Western European regions that have undergone the transition from an industrial to a post-industrial region - 
such as: the Ruhr Area (Germany), Nord-Pas-de-Calais (France), West Scotland (the United Kingdom), Limburg (the Netherlands), Wallonia (Belgium), Saxony (Germany), Saxony-Anhalt (Germany), North-West England (the United Kingdom) - creating the new development paths was associated with large financial outlays in the long term, and did not regain the former socio-economic rank of all these regions.

Due to the socio-economic changes recently determined by a greater respect towards the protection of the natural environment (European Commission, 2019), coal regions are classified as lagging-behind regions. In the EU there are 41 regions (NUTS2), in which 128 coal mines operate, extracting around 500 million tons of coal, i.e. 55\% of the coal consumption in the EU (European Commission, 2018, p. 3). The infrastructure related to the value chain of the coal sector is present in 108 regions (NUTS2), while the coal sector employs directly around 237,000 people, of which the majority work in the mines, i.e. around 185,000 people (European Commission, 2018, p. 3). The coal regions in which the number of employees in the mining sector is the highest are found mostly in Poland, then Germany, the Czech Republic, Romania, Bulgaria, Greece and Spain. In the EU, the coal region with the largest number of people employed in mines is the Silesia region in Poland with over 84,000 people directly employed in coal mines.

The key economic problem in the development of coal regions is the decrease of their competitiveness caused by the low productivity of mining activities in the era of increasing pressure on the use of renewable energy sources and in the conditions of the availability of cheaper coal from countries with lower labour costs and/or cheaper availability of this raw material (e.g. Australia, South America). In the EU during the period of 2014-2017, 32 mines were closed in Germany, Poland, Hungary, Romania, Slovakia, Slovenia, Great Britain, and Italy (European Commission, 2018, p. 4). Bearing in mind the deteriorating productivity of coal production and the pursuit of a zero-emission economy, it is expected that by 2030 further mines will be shut down. For coal regions where the mines and their value chains are located, this means a high risk of losing hundreds of thousands of direct and indirect jobs (about 160,000 jobs lose by 2030, European Commission, 2018, p. 4). The scale of economic and social changes means the problem of reorientation of coal regions' development paths refers mainly to the high dependence on mining infrastructure and underdevelopment of other sectors of the economy in these areas.

The social effects related to the deterioration of productivity in the mining sector, along with mines closing down, are compounded by the high share of direct employment in this sector, as well as indirect employment in related sectors (i.e. steel, coking coal, conventional energy, mining equipment manufacturing, quarrying and construction equipment in coal producing), which are often also located in coal regions determining the high (unfavourable) level of their economic monoculture and over-specialization. Therefore, the challenge of reorientation of coal regions requires searching for and verifying the new and modern development concepts conducive to socio-economic transition, and justifying the rational policy framework for transition. 


\section{Coal and post-coal regions in the EU}

The research question concerning the determination of the nature of the current development processes of lagging-behind regions, including coal and post-coal ones, is presented in economic categories. To this end, an analytical framework is proposed (see Figure 1) to examine the relationships between two variables reflecting the key economic parameters of the regional development, i.e. GDP dynamics and job dynamics. For both measures, the quotient of their baseline values from 2010 and current values from 2017 was taken into account. The indicated measures were calculated for 1270 EU regions from the NUTS3 level. For French regions, the NUTS2 level was used due to the lack of statistical information on growth and employment for NUTS3 regions for 2010 and 2017.

\begin{tabular}{|l|c|c|}
\cline { 2 - 3 } $\begin{array}{l}\text { Dynamics } \\
\text { of workplaces }\end{array}$ & $\begin{array}{c}\text { (3) Low economic growth \& high } \\
\text { workplaces growth } \\
\text { (public sector driven development) }\end{array}$ & $\begin{array}{c}\text { (1) High economic growth \& high } \\
\text { workplaces growth } \\
\text { (new technologies }- \text { new path })\end{array}$ \\
\cline { 2 - 3 } & $\begin{array}{c}\text { (4) Low economic growth \& slow } \\
\text { or drop } \\
\text { of workplaces growth } \\
\text { (recession - decay) }\end{array}$ \\
- & $\begin{array}{c}\text { (2) High economic growth \& slow } \\
\text { of workplaces growth } \\
\text { (improving existing technologies - } \\
\text { exploring existing path) }\end{array}$ \\
\hline
\end{tabular}

Fig. 1. Framework for analysis

Source: self-elaboration.

The proposed analytical framework allows to indicate four basic types of regions. The first quarter (I) refers to the case where high dynamics of economic growth (i.e. higher than average in the examined group of regions) is accompanied by high dynamics of job creation (i.e. higher than average in the examined group of regions). Regions located on such a development path are characterized by dynamic economic growth accompanied by new jobs. These are places where new technologies and high productivity sectors are emerging. The second quarter (II) corresponds with the case where high dynamics of economic growth is accompanied by a decrease in the number of jobs. These are places where growth is achieved by improving the efficiency of existing value chains, which results in, among others, a decrease in the number of jobs. The third quarter (III) is the case where low dynamics of economic growth is accompanied by high dynamics of job creation. These types of places may be characterized by the creation of employment in the public sector and/or the development of endogenous service sectors (characterized by low employment up to now). The last quarter (IV) refers to the case where low dynamics of economic 
growth is accompanied by low dynamics of job creation or their decline. These types of regions are in the most unfavourable situation, i.e. in closing processes, or growth processes, showing lower dynamics than the average dynamics in the examined set (i.e. low productivity). Regions qualified for the fourth quarter are labeled as lagging behind regions.

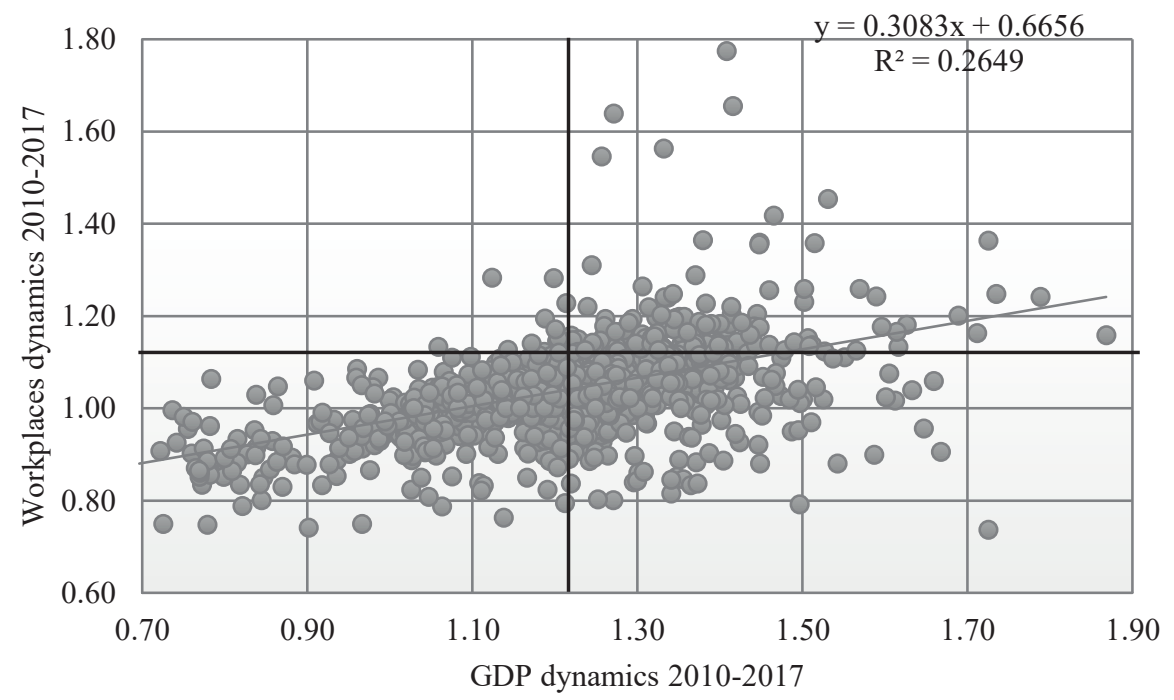

Fig. 2. The EU NUTS3 regions ( $n=1270$ NUTS3 regions)

Source: self-elaboration according to Eurostat.

Turning to the analysis of the results of the empirical study (Figure 2), it should be emphasized that the vast majority of NUTS3 regions in the EU is qualified for the II and IV quarters of the analytical framework. Quarter I (leadership regions) is also relatively numerous. The general trend among NUTS3 regions across the EU is favourable, i.e. higher growth dynamics are accompanied by higher growth of jobs (the value of parameter in the linear function is +0.31 ).

By limiting the above analysis to coal regions ${ }^{1}$ (Figure 3 ) it is evident that the vast majority of them are qualified to quarters II and IV of the analytical framework. This means that in some of them (quarter II), processes aimed at improving efficiency while reducing employment dynamics dominate, or closing processes occur which are accompanied by a decline in employment dynamics (quarter IV) in reference to the average values for NUTS3 regions in the EU. Note also that in the case of coal

1 The set of coal and post-coal regions in the EU was created by the NUTS3 level regions which fulfil the criteria of territorial eligibility for the Just Transition Fund (European Commission, 2020). This collection was expanded by the selected post-coal NUTS3 regions in the Ruhr Area in which coal mines operated in the past. 
and post-coal regions the general trend for higher dynamics associated with growth and higher employment growth occurs with lower intensity (parameter value of the linear function is +0.24 ).

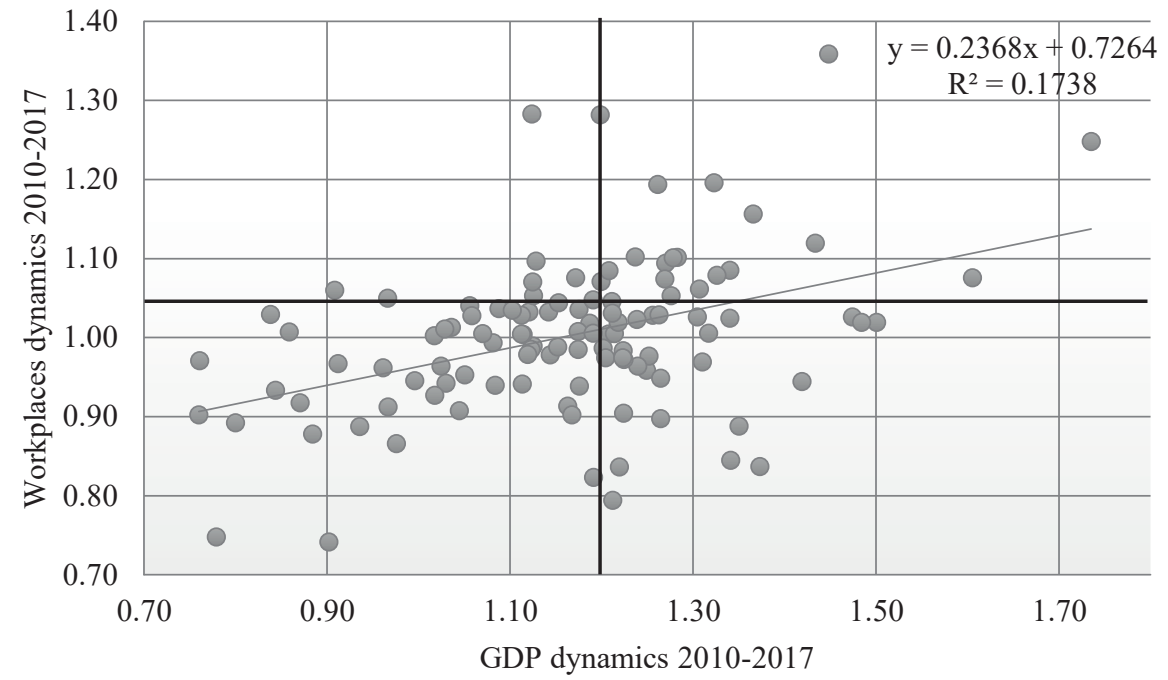

Fig. 3. The EU NUTS 3 coal and post-coal regions ( $n=111$ NUTS3 regions)

Source: self-elaboration according to Eurostat.

The coal and post-coal regions in Poland are in a more unfavourable position (Figure 4). Most of them are qualified to quarter II (Sosnowiec, Konin, Walbrzych, Piotrków) and IV (subregions: Bytom, Rybnik, Legnica and Glogow). Nevertheless, in their case there is no positive trend observed between the dynamics of economic growth and employment dynamics. In the case of Polish coal and post-coal regions - in line with the general trend depicted by the linear function - higher growth dynamics are accompanied by a decrease in employment (the value of parameter in the linear function is: -0.10 ). This means, on the one hand, that Polish coal and post-coal regions are striving to improve the efficiency of value chains by reducing employment dynamics. On the other hand, this means that in Poland there is a small group of coal and post-coal regions diversifying and reorienting their own economic structure in an effective and modern way. The exceptions refer to favourable development trends linked only with the Bielsko and Gliwice subregions in Silesia (I quarter), in which the processes of closing down the mining or traditional industries took place in the 1990s, and in which intensive activities attracting foreign direct investments and the development of local entrepreneurship led to creating a new, more diversified economic structure. 


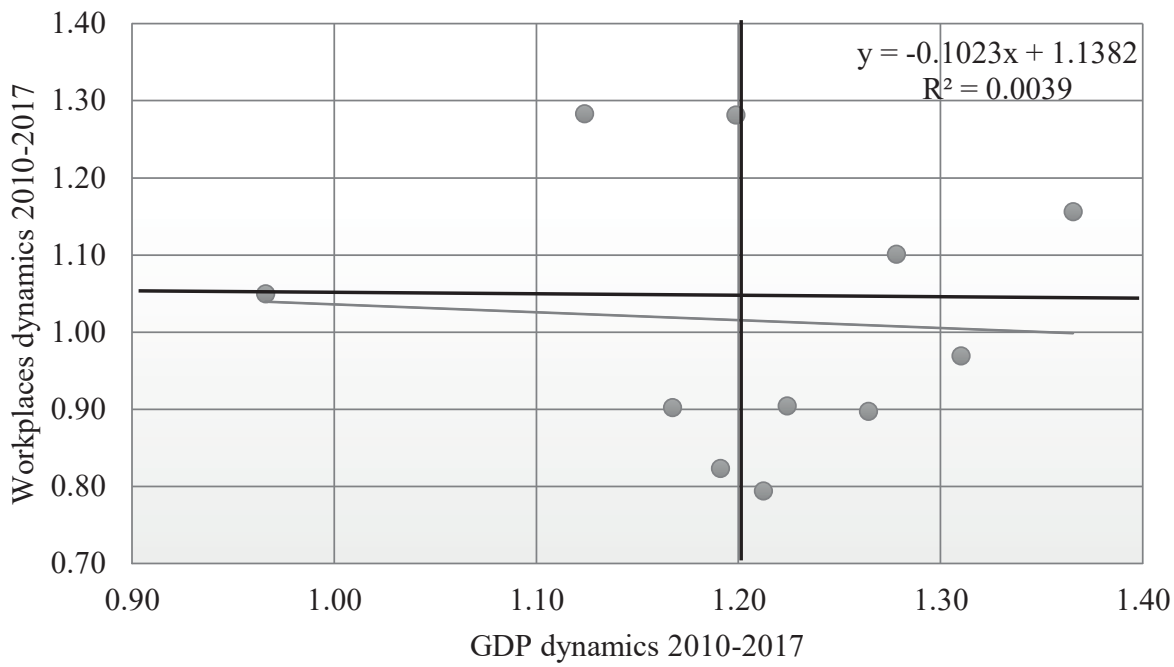

Fig. 4. The NUTS3 coal and post-coal regions in Poland ( $n=11$ NUTS3 regions)

Source: self-elaboration according to Eurostat.

A separate discussion is required for quarter III of the analytical framework, in which two subregions, i.e. Katowice and Tychy, were placed. In their case, high employment growth is not accompanied by high economic growth. This case especially in the Katowice sub-region - is associated with the creation of a relatively large number of jobs in the public sector (lower productivity), including those in local government, education, health care, and public services, which is linked with the administrative rank of the city (central city of the Silesia Metropolis).

\section{Discussion and conclusions}

The briefly presented economic nature of development processes in the lagging-behind regions, including the coal regions of the $\mathrm{EU}$, indicates that they are exhausting their current sources of competitive advantage based on traditional industries. In most coal and post-coal regions, jobs are being lost or their dynamics lower than the EU average. Even in the case of coal and post-coal regions with high economic growth, this type of growth is accompanied by employment reduction. The exceptions include coal and post-coal regions which have reoriented the growth path allowing not only for high GDP growth, but also for increasing the pool of jobs. Polish coal and post-coal regions are in an excessively difficult condition due to the scale of employment in the mining sector, but also because of the low degree of diversification of their economies. This make them exposed to high risks of reduced 
growth, a decline in demand for labour, and economic recession affecting not only the mining sector value chain, but also related sectors.

As demonstrated by examining the relationship between the dynamics of GDP growth and the dynamics of job creation, the general objective of economic development for regions is directly related to productivity improvement, preferably by diversifying the economies of lagging-behind regions with new activities. The complexity of the elements determining the desired increase in the productivity of these regions - as indicated in presented concepts of regional re-development - can based on strengthening innovation activity, building related and unrelated variety, and creating a polycentric urban regions. This requires a move away from the application of only sectoral policies (policies of this kind are a response to partial problems often without interrelationship and reference to complex causes) in favour of formulating a 'mix' policy in respect of the starting position of the lagging-behind region (position in the proposed analytical framework) together with a properly selected intervention.

A properly selected 'mix' of policies for such regions can be composed of the goals, directions, and instruments which draw from the presented modern theoretical concepts and refer to the examined territorial economic conditions of coal and post-coal regions. This policy framework for coal and post coal regions transition can include:

- minimizing the cognitive gap related to determining the future of lagging-behind regions by anticipatory studies leading to the identification of development challenges that form a realistic vision of re-development;

- minimizing the infrastructure gap in the scope of: information and communication infrastructure (ICT), environmental infrastructure, transport infrastructure (connecting a lagging-behind region with the leading regions which determines spillover effects). The aim is to reduce of the so-called 'missing links' placed in the concept of polycentric urban region;

- minimizing the institutional gap in these regions for policy coordination on structural changes focused on: research and development, ICT, human capital, entrepreneurship, economic internationalization and participation in global value chains, technical and social infrastructure, urban policy;

- minimizing the competence gap including indicating activities for effective education in order to enhance diversity and flexibility of skills and competences;

- minimizing the adaptation gap in terms of the sectoral structure of the region identification of the desired industries and sectors (related and unrelated), whose occurrence contributes to such a 'composition' of the economic structure of the region, which enhances growth, characterized by economic resilience and conducive to further growth of the region's economic diversity in the long run;

- minimizing the adaptation gap in a desired model of the regional innovation system - probably based on a hybrid of 'national regionalized', 'regionally networked' and 'territorially rooted' solutions of RIS; 
- better use of urban potentials based on the concept of a polycentric urban region using a strategic, cultural and functional approach.

It should also be emphasized that new sectors of the economy in mining and post-mining regions can clearly be based on industrial heritage. The transition towards a competitive industry and services requires, however, intensive cooperation between existing companies, investors, land-use planners, self-governments and local communities' organizations.

\section{References}

Aitken, B. J., and Harrison A. E. (1999). Do domestic firms benefit from direct foreign investment? Evidence from Venezuela. American Economic Review, (89), 605-618.

Asheim, B. T., Isaksen, A., and Trippl, M. (2019). Advanced introduction to regional innovation systems. Cheltenham, Northampton: Edward Elgar.

Bachtler, J., Martins, J. O., Wostner, P., and Zuber, P. (2019). Towards Cohesion Policy 4.0, Taylor \& Francies, Oxon, 1(1), 4-79.

Bailey, N., and Turok, I., (2001). Central Scotland as a polycentric urban region: Useful planning concept or chimera? Urban Studies, 38(4), 697-715.

Barry, F., Görg, H., and McDowell, A. (2003). Outward FDI and the investment development path of a late-industrializing economy: Evidence from Ireland. Regional Studies, (37), 341-349.

Barzotto, M., Corradini, C., Fai, F. M., Labory, S., and Tomlinson, Ph. R. (2019). Revitalising lagging regions: Smart Specialisation and Industry 4.0, Taylor \& Francis, Oxon, 1(2), 1-92.

Boschma R. A, and Franken, K. (2007). Introduction. Applications of Evolutionary Economic Geography. In K. Franken (Ed.), Applied evolutionary economics and economic geography (pp. 1-24). Cheltenham: Edward Elgar.

Boschma, R., and Immarino, S. (2009). Related variety, trade linkages, and regional growth in Italy. Economic Geography, 85(3), 289-311.

Boschma, R., Minondo, A., and Navarro, M. (2012). Related variety and regional growth in Spain. Papers in Regional Science, 91(2), 241-256.

Briguglio, L., Cordina, G., Farrugia, N., and Vella, S. (2006). Conceptualizing and measuring economic resilience. Mimeo, Department of Economics, University of Malta.

Cohen, W. M., and Levinthal, D. A. (1990). Absorptive capacity - a new perspective on learning and innovation. Administrative Science Quarterly, 35(1), 128-152.

Cooke, Ph. (1998). Introduction. Origins of the concept. In H. J. Braczyk Ph. Cooke, M. Heidenreich, Regional Innovation Systems: The role of governances in a globalized world, London: UCL Press.

Cooke, Ph., Parrilli, M. D., and Curbelo, J. L. (2012). Innovation, global change and territorial resilience. Cheltenham, Northampton: Edward Elgar.

Dijkstra, L., Poelman, H., and Rodríguez-Pose, A. (2018). Geography of EU discontent. Regional and Urban Policy (Working Paper, WP 12/2018), 2-22.

Drobniak, A. (2012). Projekty strategiczne w mieście poprzemysłowym. Katowice: Wydawnictwo Uniwersytetu Ekonomicznego w Katowicach.

Drobniak, A. (Ed.). (2014). Urban resilience concept and post-industrial cities in Europe. Gliwice: Helion.

Drobniak, A., Plac, K., and Rykała, P. (2019). Polycentric regional development in the Silesia Region and in the Upper Silesian Agglomeration - development policies and socio-economic diversity. (Presentation on the conference: Planning and Governing Polycentric Urban Regions), Loughborough University, September 2-3. 
Drobniak, A., Polko, A., and Suchacek, J. (2017). Transition and resilience in Central and Eastern European regions. In G. Horvat, and G. Lux, The Routledge Handbook to Regional Development in Central and Eastern Europe. Taylor \& Francies, Oxon, 240-260.

Duranton, G., and Puga, D. (2004). Micro-foundations of urban agglomeration economies. In Handbook of Regional and Urban Economies (pp. 2063-2117). Elsevier.

European Commission. (1999). Sixth periodic report on the social and economic situation and development of regions in the European Union. Brussels.

European Commission. (2017). Final report. Economic challenges of lagging regions. Brussels, April. European Commission. (2018). EU coal regions: Opportunities and challenges ahead. Brussels.

European Commission. (2019). The European green deal. COM, 640 final, Brussels, 11.12.

European Commission. (2020). Overview of investment guidance on the Just Transition Fund 2021-2027 per Member State. Annex D. Brussels.

Folke, C., Carpenter, S., Walker, B., Scheffer, M., Chapin, T., and Rockstom, J. (2010). Resilience thinking: Integrating resilience, adaptability and transformability. Ecology and Society, 15(4).

Fontana, M. (2013). Pluralism(s) in economics: Lessons from complexity and innovation economics: A review paper. Journal of Evolutionary Economics, 24(5), 1-16.

Frenken, K., Van Oort, F., and Verburg, T. (2007). Related variety, unrelated variety and regional economic growth, Regional Studies, (41), 685-697.

$\mathrm{Fu}, \mathrm{X}$., and Gong, Y. (2011). Indogenous and foreign innovations efforts and drivers of technological upgrading: Evidence from China. World Development, (39), 1213-1225.

Girma, S., and Wakelin, K. (2007). Local productivity spillovers from foreign direct investment in the UK electronics industry. Regional Science and Urban Economics, (37), 399-412.

Harvey, D. (2005). A brief history of neoliberalism. Oxford: Oxford University Press.

Hassink, R. (2010). Regional resilience: A promising concept to explain differences in regional economic adaptability? Cambridge Journal of Regions. Economy and Society, 3(1), 45-58.

Hendriks, F. (2006). Shifts in governance in a polycentric urban region: The case of the Dutch Randstad. International Journal of Public Administration, 29(10-11), 931-951.

Houtum, H., and Lagendijk, A. (2001). Contextualising regional identity and imagination in the construction of polycentric urban regions: The cases of the Ruhr Area and the Basque Country. Urban Studies, 38(4), 747-767.

Krzysztofik, R. (2012). Mieszkamy w czołówce najbardziej odpychających miast w Polsce. Gazeta Wyborcza, 8 sierpnia.

Kwon, K., and Seo, M. (2018). Does the polycentric urban region contribute to economic performance? The case of Korea. Sustainability, 10(4157), 1-10.

Lundvall, B., and Johnson, B. (1994). The learning economy. Journal of Industry Studies, 1(2), 23-42.

Martin, R., and Gardiner, B. (2019). The resilience of cities to economic shocks: A tale of four recessions (and the challenge of Brexit). Papers in Regional Science, 1-32.

Martin, R., and Sunley, P. (2006). Path dependence and regional economic evolution, Journal of Economic Geography, (6), 395-437.

Martin, R., and Sunley, P. (2007). Complexity thinking and evolutionary economic geography. Journal of Economic Geography, (7), 573-602.

Micek, G. (2017). Bliskość geograficzna przedsiębiorstw zaawansowanego przemystu i ustug a przepływy wiedzy. Kraków: Instytut Geografii i Gospodarki Przestrzennej, Uniwersytet Jagielloński w Krakowie.

Pasinetti, L. L. (1993). Structural economic dynamics. Cambridge: Cambridge University Press.

Phelps, N., and MacKinnon, D., (2000), Industrial enclaves or embedded form of economic activity? Overseas manufacturing investment in Wales. Contemporary Wales, (13), 46-67.

Rodríguez-Pose, A. (2018). The revenge of the places that don't matter (and what to do about it). Cambridge Journal of Regions, Economy and Society, 11(1), 189-209. 
Rogers, E. M. (2003). Diffusion of innovation. New York: Free Press.

Simmie, J., and Martin, R. (2009). The economic resilience of regions: Towards an evolutionary approach. Cambridge Journal of Regions, Economy and Society, 3(1), 27-43.

Solheim, M. C. W., Boschma, R., and Herstad, S. (2018). Related variety, unrelated variety and the novelty content of firm innovation in urban and non-urban locations. Papers in Evolutionary Economic Geography, 18(36), 1-31.

Taylor, P. J., and Pain, K. (2007). Polycentric mega-city regions: Exploratory research from Western Europe. The Healdsburg Research Seminar on Megaregions, April 4-6.

Weber, K. M., and Truffer, B. (2017). Moving innovation systems research to the next level: Towards an integrative agenda. Oxford Review of Economic Policy, 33(1), 101-121. 